\title{
THE ROLE OF CALCIUM, PHOSPHORUS AND VITAMIN D IN PREGNANCY ${ }^{1}$
}

\author{
By H. O. NICHOLAS AND EVELYN M. KUHN \\ (From the Department of Chemistry, The Rice Institute, Houston, Texas)
}

(Received for publication August 1, 1932)

Within recent years the importance of calcium and phosphorus in the diet in pregnancy has received considerable attention. In considering the nutritional value of these elements, it was also quite natural that the rôle played by vitamin $\mathrm{D}$ should be investigated. The value of these substances has been studied particularly from the standpoint of pathological conditions of pregnancy; viz., osteomalacia and eclampsia. Maxwell, Miles and Feng $(1,2)$ have made a rather complete study of osteomalacia in China and found that this condition could be relieved by placing the mothers on a high calcium and phosphorus diet supplemented by vitamin D. Hughes et al (3) in India, likewise had excellent results with this same treatment. Also, in the toxemias of pregnancy some interesting observations have been reported from the use of vitamin $\mathrm{D}$ and calcium. Richardson (4) reports favorable results in the treatment of eclampsia with large doses of vitamin D, and Minot and Cutler (5) give good evidence that a high calcium diet or calcium salts intravenously will relieve the symptoms of eclampsia.

It seemed advisable, therefore, to make a study of the effect of these three agents in pregnancy, primarily from the standpoint of the transmission of calcium and phosphorus from the mother to the fetus. The primary object of the investigation was to see if the ash content of the fetus could be controlled by the character of the maternal diet; and secondly to determine whether or not there was any perceptible evidence of a drain by the fetus on the calcium and phosphorus content of the maternal bone. There are only two papers bearing on this particular phase of the subject, of which we are aware. Maxwell, Miles and Feng $(1,2)$ in their work, analysed the fetal bones of stillborns from osteomalacic mothers, and noted some decrease in the normal ash content; and Toverud (6) carried several rats through pregnancy on a low calcium diet and noted a decrease in the ash, calcium and phosphorus content of the maternal femurs.

${ }^{1}$ Constructed from the thesis presented by Miss Evelyn M. Kuhn to the Faculty of the Rice Institute in partial fulfillment of the requirements for the Degree of Master of Arts, June 1932. 


\section{METHODS}

All rats used in this investigation were raised from our own stock. They were from four to six months old, and had been fed on the control diet (see below) up to the time of mating. Immediately after mating, the females were placed on one of the experimental diets throughout the term of pregnancy. The composition of the diets used was as follows:

1. Control diet. This consisted of the basic diet supplemented by fresh green vegetables and fruits, butter, yeast and cod liver oil.

2. Basic diet. This had the following composition: linseed oil meal, 15 parts; ground barley, 10 parts; wheat flour, 22 parts; dried buttermilk, 15 parts; rolled oats, 15 parts; yellow corn meal, 20 parts; steamed bone meal, 1 part; ground limestone, 1 part; salt, 1 part. On analysis, this diet was found to contain $97 \mathrm{mgm}$. calcium and $50 \mathrm{mgm}$. phosphorus per 10 gram portion.

3. Deficient diet. This consisted of : wheat flour, 22 parts; yellow corn meal, 77 parts; salt, 1 part. On analysis, this diet contained $13 \mathrm{mgm}$. calcium and $20 \mathrm{mgm}$. phosphorus per 10 gram portion.

Some of the pregnant rats which were being fed either the basic or the deficient diet were also given $0.5 \mathrm{cc}$. of viosterol $250 \mathrm{D}^{2}$ daily. Great care was taken to insure the rats getting this full amount of vitamin $D$. A small portion of the food was moistened with the oil, and this was eaten by the rats before the remainder of the food was given them.

In connection with this feeding of viosterol and the pregnancy of the rat, a very interesting phenomenon was noticed. The pregnant rats on either the basic or deficient diets without viosterol, mated and delivered their litters with normal expectancy; i.e. on both diets six out of seven rats which had been mated, delivered their litters at the end of the 22 day gestation period. Also the two rats which were maintained on the control diet went through their pregnancies without any trouble. These figures represent an actual diagnosis of pregnancy followed by normal delivery in 14 out of 16 attempts at mating.

On the other hand, those rats who were immediately given the $0.5 \mathrm{cc}$. of viosterol after mating did not come through their pregnancies with such regularity. Of 5 rats who were mated and then immediately placed on the deficient diet with viosterol, only one (rat number 15, Table I) came to normal term, while of 7 more rats who were also on the deficient diet but who did not receive the viosterol except during the last 10 to 14 days of their pregnancies, 5 came to normal term. That is, only six out of twelve rats went through their pregnancies when given viosterol with a diet poor in calcium and phosphorus. Still lower was the percentage of successful pregnancies in the rats fed the basic diet with viosterol added. Of 5 rats who were given viosterol during the 22 day period, none pro-

${ }^{2}$ We are greatly indebted to Mead Johnson and Co., Evansville, Ind., for the generous supply of Viosterol $250 \mathrm{D}$ used in this work. 
duced any young; and only two rats, out of 10 mated, delivered their litters when given the viosterol only during the last 14 days of pregnancy. This represents only two successful pregnancies out of fifteen attempts. The reason for this seemingly contraceptive action of viosterol, particularly on the basic diet, has not been studied by us, nor has it been previously reported as far as we are aware. That this effect could not be one of environmental or climatic conditions is ruled out, inasmuch as the

TABLE I

Calcium and phosphorus content of maternal bone ash and of the offspring

\begin{tabular}{|c|c|c|c|c|c|c|c|c|c|}
\hline \multicolumn{5}{|c|}{ Mother rat } & \multirow{2}{*}{$\begin{array}{c}\text { Number } \\
\text { of pups } \\
\text { per } \\
\text { litter }\end{array}$} & \multicolumn{4}{|c|}{ Averages of pups in litters } \\
\hline Diet & Number & Weight & $\underset{\text { cium }}{\text { Cal- }}$ & $\begin{array}{l}\text { Phos- } \\
\text { phorus* }\end{array}$ & & Weight & Ash $†$ & $\underset{\text { cium }}{\text { Cal- }}$ & $\begin{array}{c}\text { Phos- } \\
\text { phorus } †\end{array}$ \\
\hline Control & $\begin{array}{l}1 \\
2\end{array}$ & $\begin{array}{c}\text { grams } \\
153 \\
142\end{array}$ & $\begin{array}{c}\text { per cent } \\
34.2 \\
35.0\end{array}$ & $\begin{array}{c}\text { per cent } \\
16.2 \\
17.1\end{array}$ & $\begin{array}{r}10 \\
7\end{array}$ & $\begin{array}{l}\text { grams } \\
4.85 \\
5.07\end{array}$ & $\begin{array}{r}\text { mgm. } \\
91.3 \\
92.2\end{array}$ & $\begin{array}{c}m g m . \\
13.8 \\
13.9\end{array}$ & $\begin{array}{l}m g m . \\
14.1 \\
14.1\end{array}$ \\
\hline Basic & $\begin{array}{l}3 \\
4 \\
5 \\
6 \\
7 \\
8\end{array}$ & $\begin{array}{l}134 \\
145 \\
139 \\
143 \\
148 \\
150\end{array}$ & $\begin{array}{l}34.3 \\
35.8 \\
33.8 \\
35.4 \\
35.4 \\
35.0\end{array}$ & $\begin{array}{l}17.1 \\
17.3 \\
16.8 \\
16.6 \\
17.1 \\
16.8\end{array}$ & $\begin{array}{l}7 \\
8 \\
7 \\
9 \\
5 \\
6\end{array}$ & $\begin{array}{l}4.85 \\
5.15 \\
4.86 \\
4.60 \\
4.99 \\
5.06\end{array}$ & $\begin{array}{l}90.7 \\
91.8 \\
92.4 \\
86.9 \\
90.9 \\
87.7\end{array}$ & $\begin{array}{l}13.4 \\
12.8 \\
13.4 \\
13.3 \\
13.9 \\
12.8\end{array}$ & $\begin{array}{l}13.1 \\
13.6 \\
13.2 \\
13.5 \\
14.3 \\
13.3\end{array}$ \\
\hline $\begin{array}{c}\text { Basic + } \\
\text { viosterol }\end{array}$ & $\begin{array}{r}9 \\
10\end{array}$ & $\begin{array}{l}172 \\
189\end{array}$ & $\begin{array}{l}40.3 \\
38.2\end{array}$ & $\begin{array}{l}17.8 \\
17.5\end{array}$ & $\begin{array}{l}6 \\
6\end{array}$ & $\begin{array}{l}6.03 \\
5.90\end{array}$ & $\begin{array}{l}114.3 \\
113.3\end{array}$ & $\begin{array}{l}18.9 \\
19.0\end{array}$ & $\begin{array}{l}14.9 \\
15.0\end{array}$ \\
\hline Deficient & $\begin{array}{l}11 \\
12 \\
13\end{array}$ & $\begin{array}{l}117 \\
145 \\
133\end{array}$ & $\begin{array}{l}31.9 \\
33.0 \\
32.6\end{array}$ & $\begin{array}{l}14.4 \\
15.0 \\
14.5\end{array}$ & $\begin{array}{l}8 \\
6 \\
8\end{array}$ & $\begin{array}{l}4.63 \\
5.08 \\
4.52\end{array}$ & $\begin{array}{l}77.8 \\
87.6 \\
75.6\end{array}$ & $\begin{array}{l}10.6 \\
11.9 \\
10.5\end{array}$ & $\begin{array}{l}13.4 \\
12.9 \\
11.0\end{array}$ \\
\hline $\begin{array}{c}\text { Deficient } \\
+ \\
\text { viosterol }\end{array}$ & $\begin{array}{l}14 \\
15 \\
16 \\
17 \\
18 \\
19\end{array}$ & $\begin{array}{l}205 \\
139 \\
142 \\
141 \\
161 \\
155\end{array}$ & $\begin{array}{l}37.2 \\
38.0 \\
35.7 \\
35.7 \\
36.3 \\
36.3\end{array}$ & $\begin{array}{l}17.8 \\
18.0 \\
16.5 \\
17.3 \\
17.6 \\
17.6\end{array}$ & $\begin{array}{r}8 \\
7 \\
6 \\
5 \\
10 \\
11\end{array}$ & $\begin{array}{l}5.95 \\
4.56 \\
4.96 \\
5.01 \\
4.72 \\
4.12\end{array}$ & $\begin{array}{l}96.5 \\
80.7 \\
85.2 \\
90.8 \\
75.9 \\
72.9\end{array}$ & $\begin{array}{l}14.7 \\
12.5 \\
13.1 \\
11.8 \\
12.9 \\
12.4\end{array}$ & $\begin{array}{l}14.4 \\
11.8 \\
13.7 \\
13.6 \\
12.2 \\
11.8\end{array}$ \\
\hline
\end{tabular}

* Calcium and phosphorus content of the ash of the femurs and tibias.

$\dagger$ Average ash, calcium and phosphorus content in the body of the offspring.

rats without the viosterol were mating and delivering at the same time that the viosterol-fed rats were failing. No attempt will be made by us to interpret these findings.

Immediately after birth, and before suckling, the litters were removed. Each rat pup was individually etherized, weighed and ashed to constant weight in an electric muffle furnace at dull red heat. The pure-white ash was weighed, dissolved in dilute acid and made up to a suitable volume. Aliquots of this solution were used for the calcium and phosphorus determinations. In analyzing the maternal bones, the femurs and tibias 
were dissected out, and were ashed according to the method of Morgulis (7) by heating the bones to $250^{\circ} \mathrm{C}$. with a glycerole solution of potassium hydroxide. Upon the resulting bone ash, determinations for calcium and phosphorus were made. All calcium determinations were made according to the method of Roe and Kahn (8), and the phosphorus determinations by the method of Fiske and Subbarow (9).

\section{RESULTS AND DISCUSSION}

It is unnecessary to give the individual weight, ash, calcium and phosphorus data on each of the 140 rat pups which resulted from the nineteen pregnancies. Table I gives the average weight, ash, calcium and phosphorus contents of the pups in the individual litters, as well as the analytical data on the corresponding mothers. Table II condenses

TABLE II

The influence of diet on the calcium and phosphorus content of maternal bone ash and of the offspring

\begin{tabular}{|c|c|c|c|c|c|c|c|c|c|}
\hline \multicolumn{3}{|l|}{ Mother rat } & \multicolumn{7}{|c|}{ Averages of pups } \\
\hline Diet & $\begin{array}{l}\text { Cal- } \\
\text { cium* }\end{array}$ & $\begin{array}{l}\text { Phos- } \\
\text { phorus* }\end{array}$ & Weight & Ash† & $\begin{array}{c}\text { Cal- } \\
\text { ciumt }\end{array}$ & $\begin{array}{l}\text { Phos- } \\
\text { phorust }\end{array}$ & $\begin{array}{c}\text { Ash } \\
\text { per } \\
\text { gram } \\
\text { weight }\end{array}$ & $\begin{array}{c}\text { Cal- } \\
\text { cium } \\
\text { per } \\
\text { gram } \\
\text { weight }\end{array}$ & $\begin{array}{l}\text { Phos- } \\
\text { phorus } \\
\text { per } \\
\text { gram } \\
\text { weight }\end{array}$ \\
\hline & $\begin{array}{l}\text { per } \\
\text { cent }\end{array}$ & $\begin{array}{l}\text { per } \\
\text { cent }\end{array}$ & grams & $m g m$. & $m g m$. & mgm. & mgm. & mgm. & $m g m$. \\
\hline Basic + viosterol. & 39.2 & 17.7 & 5.96 & 113.8 & 19.0 & 15.0 & 19.1 & 3.2 & 2.5 \\
\hline Basic (and control). & 34.8 & 16.9 & 4.93 & 90.5 & 13.4 & 13.6 & 18.3 & 2.7 & 2.8 \\
\hline Deficient + viosterol & 36.5 & 17.5 & 4.89 & 83.7 & 12.9 & 12.9 & 17.1 & 2.6 & 2.6 \\
\hline Deficient. ......... & 32.5 & 14.6 & 4.74 & 80.3 & 11.0 & 12.4 & 16.9 & 2.3 & 2.6 \\
\hline
\end{tabular}
tibias.

* Average calcium and phosphorus content of the ash of the femurs and

† Average ash, calcium and phosphorus content in the body of the offspring

and summarizes the data of the preceding table, giving by diets, the average values obtained on both mothers and pups. It will be noted that in Table II, the two rats fed on the control diet are grouped with the six that were fed the basic diet. This is permissible since the data show that there is no difference between the mother rats and pups on these two diets, which fact also indicates that at least for the duration of the experiment the basic diet was entirely adequate for the normal maintenance of the mother rat.

The growth-promoting effect of viosterol on the fetus is quite pronounced, as can be seen from Table II. The mothers on the viosterol diet produced larger pups than those on the corresponding diets without viosterol. Likewise, the absolute ash, calcium and phosphorus contents of the pups were greater under the influence of viosterol, and so were the 
relative ash and calcium contents (i.e. ash and calcium per gram pup weight). The variation in the relative phosphorus content was not so great, with a tendency to run inversely to the relative calcium content.

The variation in the calcium and phosphorus content of the maternal bones was also quite noticeable. Both groups of viosterol-fed mothers showed higher contents of these two elements than did the mothers not receiving the viosterol. It has already been pointed out that mothers on the viosterol diet produced young who had a greater content of calcium and phosphorus in them, than corresponding offspring from the mothers not receiving the viosterol. It is evident, therefore, that viosterol exerts its influence in two ways. In the first place, vitamin $D$ exhibits a prenatal effect on the fetus, by forcing or allowing the fetus to take more calcium and phosphorus from the maternal organism, than it would ordinarily get from the mother on a normal or limited diet. This extra drain by the fetus (under the influence of viosterol) would be expected to deplete the maternal bones of calcium and phosphorus, unless there was some protection offered to them. Therefore, in the second place, the viosterol offers this protection by causing better assimilation of the large or small amount of calcium and phosphorus in the mothers' diets, so that there is actually an over-abundance of these elements laid down in the maternal bones to counteract the excessive drain by the fetus. An interesting picture is presented in the deficient + viosterol group wherein the calcium and phosphorus content of the maternal bones is greater than in the basic group, although the calcium and phosphorus content of the diet is considerably less than in the diet of the basic group. However, the offspring from the deficient + viosterol do not have as great ash, calcium and phosphorus content as do those from the basic group mothers. These facts seem to indicate that the viosterol exhibits a relatively greater effect in promoting assimilation of calcium and phosphorus from the diet by the maternal organism, than in increasing the transmission of these elements from the mother to the fetus.

The only real evidence of any actual drain by the fetus on the maternal bone can be shown by comparing the basic and the deficient groups. In these groups the mothers received no viosterol. The mothers fed on the basic diet showed a higher content of bone calcium and phosphorus and their young showed more ash, calcium and phosphorus than did the mothers and young from the deficient diet. Comparing these two groups with two similar groups of non-pregnant female rats of the same age, and fed on the same diets for 22 days, one can see the evidence of a drain by the fetus on the ash content of the maternal bone. On analysis, the calcium content of the bone of 3 normal non-pregnant females fed on the basic diet was 35.0 per cent, and the phosphorus content was 17.0 per cent. These values compare well with those obtained from pregnant rats on the basic diet. The calcium and phosphorus content of the maternal bone 
of 2 normal non-pregnant rats kept on the deficient diet for 22 days was 34.2 and 16.9 per cent respectively. Comparing these values with those of the pregnant rats on the deficient diet, there is noted a considerable decrease in the calcium content of the bone of the pregnant rat, and this decrease is more noticeable in the phosphorus content. In the two groups of viosterol-fed rats this drain was not noticeable, since the assimilating effect of the viosterol overshadowed the lesser prenatal effect of transmission of calcium and phosphorus from the mother to the fetus.

\section{SUMMARY}

1. Pregnant rats fed on high and low calcium and phosphorus containing diets with added large doses of viosterol $250 \mathrm{D}$ produced larger young, which contained greater amounts of ash, calcium and phosphorus than did young coming from mothers on the same diets without the viosterol.

2. The results show definite evidence of a drain on the calcium and phosphorus content of the maternal bone by the fetus only in the case of the mother rats kept on the deficient diet. These bones, which contained 32.5 and 14.6 per cent of calcium and phosphorus respectively, when compared to the calcium content of 34.2 and phosphorus content of 16.9 per cent as found in bones of non-pregnant females, show definite evidence of bone depletion by the fetus.

3. In pregnancy, viosterol plays a dual rôle. In the first place, it exhibits its well-known normal effect of causing better assimilation of the calcium and phosphorus in the diet by the maternal organism, and secondly, it seems to have a prenatal effect of allowing better transmission of calcium and phosphorus from the mother to the fetus.

4. Evidence of the possible interfering action of viosterol on the progress of a normal pregnancy is indicated.

\section{BIBLIOGRAPHY}

1. Maxwell, J. P. and Miles, L. M., J. Obst. and Gynec. Brit. Emp., 1925, xxxii, 433. Osteomalacia in China.

2. Miles, L. M. and Feng, C-T., J. Exper. Med., 1925, xli, 137. Calcium and Phosphorus Metabolism in Osteomalacia.

3. Hughes, T. A., Schrivastava, D. L., Sahai, P. N. and Malik, K. S., Indian J. Med. Res., 1930-31, xviii, 517. Further Observations on the Serum Calcium and Plasma Cholesterol in Health and Disease, and the Blood Chemistry in Osteomalacia.

4. Richardson, G. C., Illinois Med. J., 1931, lix, 453. Rôle of Viosterol in Pregnancy.

5. Minot, A. S. and Cutler, J. T., Proc. Soc. Exper. Biol. and Med., 1929, xxvi, 607. Increase in Guanidine-like Substance in Acute Liver Injury and Eclampsia.

6. Toverud, G., J. Biol. Chem., 1923-4, lviii, 583. The Influence of Diet on Teeth and Bones. 
7. Morgulis, S., J. Biol. Chem., 1931, xciii, 455. Studies on the Chemical Composition of Bone Ash.

8. Roe, J. H. and Kahn, B. S., J. Biol. Chem., 1929, 1xxxi, 1. The Colorimetric Determination of Blood Calcium.

9. Fiske, C. H. and Subbarow, Y., J. Biol. Chem., 1925, 1xvi, 375. The Colorimetric Determination of Phosphorus. 